\title{
The study of the interactions between Sava River and Zagreb aquifer system (Croatia) using water stable isotopes
}

\author{
Jelena Parlov ${ }^{1, *}$, Zoran Kovač ${ }^{1}$, and Jadranka Barešić $^{2}$ \\ ${ }^{1}$ University of Zagreb, Faculty of Mining, Geology and Petroleum Engineering, Zagreb, Croatia \\ ${ }^{2}$ Ruđer Bošković Institute, Zagreb, Croatia
}

\begin{abstract}
Water stable isotopes were used to investigate hydrological pathways and interactions between surface water and groundwater in the Zagreb aquifer system (Croatia). $\delta^{2} \mathrm{H}$ and $\delta^{18} \mathrm{O}$ values indicate a spatial variability of the influence of individual groundwater sources inside the aquifer - local precipitation and the Sava River water. Fractions of surface water in groundwater strongly depend on fluctuations of the river water level and less on the distance from the Sava River. These data extend our understanding of groundwater flow in the Zagreb aquifer system, interactions between Sava River water, local precipitation and groundwater. The results of the research allow more precise monitoring plans and definition of the sanitary protection zones of the well fields in the future.
\end{abstract}

\section{Introduction}

The Zagreb aquifer presents the main source of potable water for the City of Zagreb and part of Zagreb County, and is protected by Croatian state government. The fluctuations of the Sava River water levels cause fluctuations in the groundwater levels of the Zagreb aquifer, especially in the vicinity of the Sava River. Groundwater levels are declining in average 1-2 m per decade, generally due to lowering of Sava River bed and excessive pumping. At the moment, groundwater for water supply is pumped from five different well fields but due to constant decrease of groundwater levels and possible groundwater quantity issues, especially in dry periods, construction of a new regional well-field Kosnica is in progress. Kosnica well-field is considered in the future as a main well-field supplier and the location of recharge areas is of prime concern, as such areas have to be protected in order to preserve good groundwater quality and quantity. Groundwater often consists of a mixture of recharge from surface water (lakes or rivers) and local precipitation. It is important to know the proportions of these recharge components in order to increase the sustainable supply of drinking water through bank infiltration, and to prevent drinking water pollution by infiltration of water from a contaminated surface water source.

\footnotetext{
*Corresponding author: jelena.parlov@rgn.hr
} 


\section{Site description}

The Zagreb aquifer system is located in the NW part of the Republic of Croatia, in the urban area of the Croatian capital, along the Sava River (Fig.1). Two different aquifers are encountered in the profile. The first, shallow unconfined aquifer, comprises gravel and sand transported by the river from the Alps during Holocene and deposited in this region. This layer is 5 to 10 meters thick in the western part and up to 40 meters in the eastern part. The second aquifer is built of sand and gravel deposits of lacustrine-marsh facies, brought into this area by streams, from the surrounding mountains. It is up to 20 meters thick in the western part and up to 60 meters in the eastern part. An overburden is not thick, generally up to two meters. The naturally thin overburden has been additionally devastated and actually presents no protection against surface contamination. Zagreb aquifer is an unconfined aquifer with general groundwater flow directions from west to east, southeast. Water supply is based on the first shallow aquifer. Head contour maps analysis showed that during high Sava river water levels (HGWL) the river infiltrates groundwater on all parts of the flow while during medium and low water levels (LGWL) the river drains groundwater on some parts of the flow [1].

\section{Sampling and methods}

Different recharge components can be identified through the stable isotope compositions of groundwater $\left(\delta^{2} \mathrm{H}\right.$ and $\left.\delta^{18} \mathrm{O}\right)$ because of different isotope composition of end components and evaporation in surface water bodies. Samples for determination of isotopic composition, $\delta^{2} \mathrm{H}$ and $\delta^{18} \mathrm{O}$, were collected monthly during 2010 [2], 2011 and 2016 in the Sava River, precipitation (Zagreb-Grič, meteorological station included in GNIP-Global Network of Isotopes in Precipitation) and groundwater at 17 observation wells close to the Sava River (Table 1 and Fig. 1). Water stable isotopes were determined by liquid water isotope analyser produced by Los Gatos Research. Stable isotope measurements of oxygen and hydrogen were performed in 284 samples. Data was prepared, processed and interpreted in LIMS (laboratory information management system). Results are reported using conventional delta $(\delta)$ notation, respectively, in permil $(\%)$ relative to VSMOW (Table 1).

A fraction of local precipitation versus the Sava River water in groundwater was calculated by the two-component mixing model. The contribution of both sources could be estimated using the following equations:

$$
\begin{gathered}
\delta^{18} O_{G W}=f_{S W} x \delta^{18} O_{S W}+f_{P} x \delta^{18} O_{P} \\
\quad l=f_{S W}+f_{P}
\end{gathered}
$$

where $f_{S W}$ and $f_{P}$ are respective surface water (Sava River) and precipitation fractions, while $\delta^{18} \mathrm{O}_{\mathrm{GW}}, \delta^{18} \mathrm{O}_{\mathrm{SW}}$, and $\delta^{18} \mathrm{O}_{\mathrm{P}}$ are the isotopic compositions of oxygen in groundwater, surface water and precipitation, respectively.

\section{Results and discussion}

The focus of the paper is related to $\delta^{2} \mathrm{H}$ and $\delta^{18} \mathrm{O}$ mean values in groundwater, the Sava River water and precipitation. In precipitation $\delta^{18} \mathrm{O}$ values ranged from $-14.64 \%$ o to $-3.34 \%$ o with mean of $-9.44 \%$, but since the seasonal variation (Fig. 2) is normal for the Northern Hemisphere [3] for calculation of isotope mass balance long term means of $\delta^{18} \mathrm{O}(-8.04 \%$ ) from Global Network of Isotopes in Precipitation (GNIP database) were used. Data 
obtained during 2010, 2011 and 2016 are comparable, but insufficient due to the noncharacteristic years (extremely dry and wet). $\delta^{18} \mathrm{O}$ values of the Sava River water ranged from $-10.33 \%$ to $-8.54 \%$ and $\delta^{2} \mathrm{H}$ values ranged from $-69.9 \%$ o to $-55.6 \%$ with the mean $\delta^{18} \mathrm{O}$ value of -9.47 and the mean $\delta^{2} \mathrm{H}$ value of -62.8 . The $\delta^{18} \mathrm{O}$ values of groundwater ranged from $-9.3 \%$ in A-2-1 to $-9.07 \%$ in PP $23 / 5$ with the mean $\delta^{18} \mathrm{O}$ value of -9.19 . The $\delta^{2} \mathrm{H}$ values ranged from $-62.8 \%$ in Čdp- $8 / 2$ to $-60.4 \%$ in $\mathrm{PZ}-33$ with the mean $\delta^{2} \mathrm{H}$ value of -61.4 (Table 1).

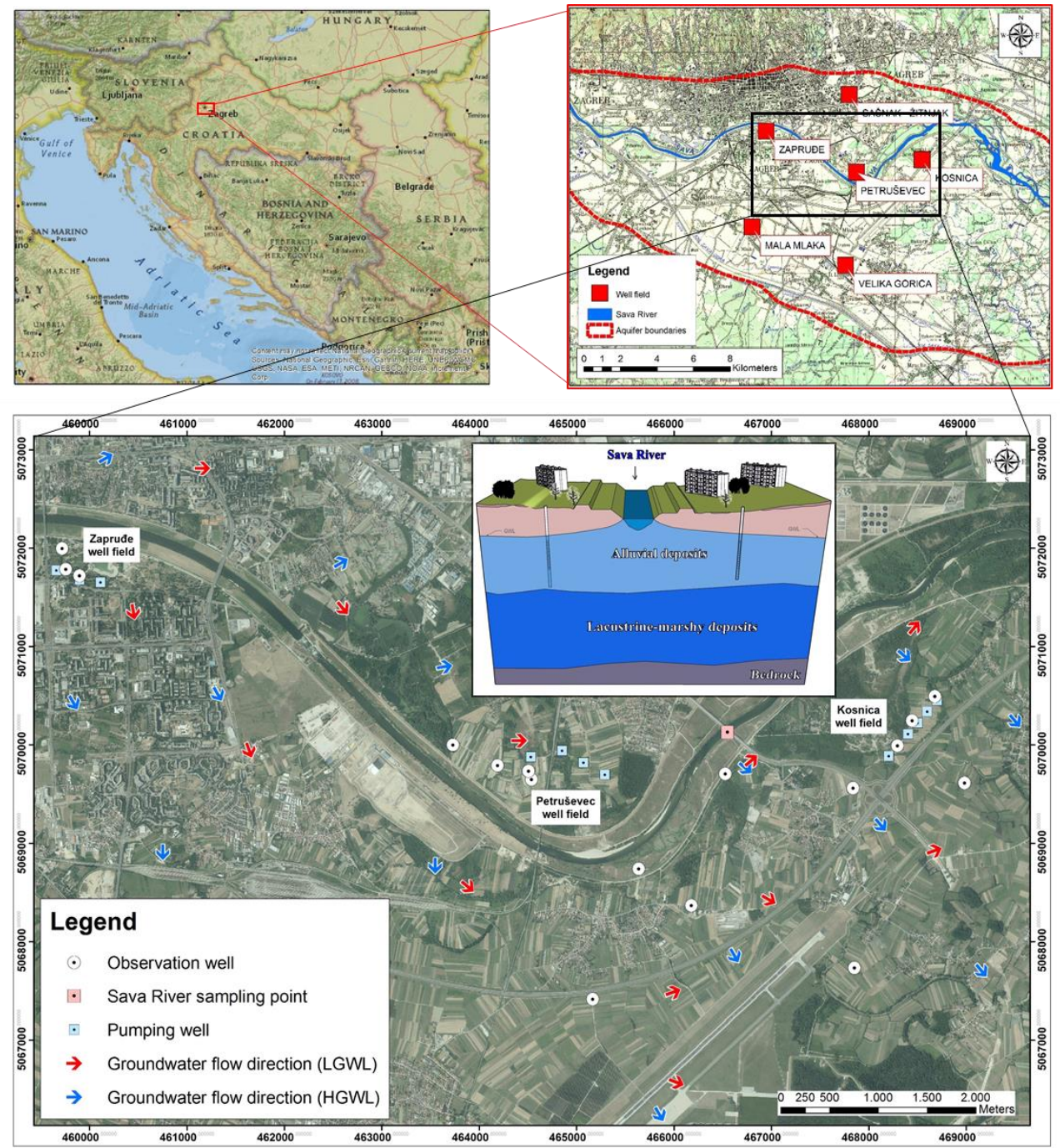

Fig. 1. Zagreb aquifer system location with the groundwater flow directions and sampling point locations.

The mean $\delta^{18} \mathrm{O}$ and $\delta^{2} \mathrm{H}$ values of groundwater samples plot near the Sava River regression line showing that groundwater is dominantly influenced by the recharge from the Sava River water (Fig. 3), but isotope fingerprints still detect infiltrated local precipitation. Based on the mean $\delta^{18} \mathrm{O}$ and $\delta^{2} \mathrm{H}$ values cannot be clearly defined any group of wells. Thus, a simple isotope mass-balance calculation was performed, using Eqs. (1) and (2), to estimate fractions of each recharge water types in the aquifer. The results of this calculation 
are presented in Fig. 3. Fractions of the Sava river water in all observation wells are extremely high. Values ranged from 72 to $88 \%$. The differences in values do not correlate with the distance of the observation well from the river but could be explained by geological properties of the aquifer and groundwater flow directions. Uneven spatial overburden distribution and land usage, that varies from agricultural to urbanized, also have an influence to aquifer recharge from precipitation.

Table 1. Coordinates, minimum, maximum, mean and number of samples for $\delta^{2} \mathrm{H}$ and $\delta^{18} \mathrm{O}$ at sampling locations (Blue - Kosnica well field, black-Petruševec well field, red-Zapruđe well field).

\begin{tabular}{|c|c|c|c|c|c|c|c|c|c|}
\hline \multirow{2}{*}{$\begin{array}{l}\text { Sampling } \\
\text { location }\end{array}$} & \multicolumn{2}{|c|}{$\begin{array}{c}\begin{array}{c}\text { HTRS96/TM } \\
\text { coordinates }\end{array} \\
\end{array}$} & \multirow{2}{*}{$\begin{array}{c}\text { No. of } \\
\text { samples }\end{array}$} & \multicolumn{3}{|c|}{$\delta^{18} \mathrm{O}(\%)$} & \multicolumn{3}{|c|}{$\delta^{2} \mathrm{H}(\%)$} \\
\hline & $\mathrm{N}(\mathrm{m})$ & $\mathrm{E}(\mathrm{m})$ & & Mean & Min & Max & Mean & Min & Max \\
\hline A-2-1 & 5067416 & 465165 & 12 & -9.30 & -9.38 & -9.21 & -62.3 & -63.3 & -61.3 \\
\hline Čdp-12/3 & 5069560 & 467839 & 12 & -9.19 & -9.38 & -9.07 & -61.3 & -62.3 & -60.1 \\
\hline Čdp-13/1 & 5067734 & 467853 & 12 & -9.16 & -9.32 & -9.05 & -61.0 & -62.0 & -60.4 \\
\hline Čdp-8/2 & 5068367 & 466178 & 12 & -9.29 & -9.45 & -9.17 & -62.6 & -63.6 & -61.1 \\
\hline Čp-101 & 5069707 & 466526 & 12 & -9.27 & -9.57 & -9.11 & -61.9 & -62.6 & -61.1 \\
\hline Čp-8 & 5069614 & 468983 & 12 & -9.09 & -9.24 & -8.94 & -60.7 & -61.3 & -60.3 \\
\hline Mp-5 & 5068740 & 465639 & 12 & -9.24 & -9.54 & -8.66 & -62.0 & -64.1 & -57.0 \\
\hline Pkb-1/1/3 & 5070495 & 468679 & 12 & -9.12 & -9.24 & -9.01 & -61.2 & -63.0 & -60.3 \\
\hline Pkb-3/1/3 & 5070247 & 468446 & 12 & -9.21 & -9.49 & -8.98 & -61.4 & -62.0 & -60.5 \\
\hline Pkb-5/1/3 & 5069991 & 468293 & 12 & -9.23 & -9.48 & -9.07 & -62.3 & -63.6 & -61.1 \\
\hline PP 18/30 & 5069791 & 464189 & 12 & -9.09 & -9.57 & -8.71 & -61.0 & -63.8 & -57.5 \\
\hline PP 19 & 5069650 & 464539 & 12 & -9.20 & -9.47 & -8.94 & -60.7 & -63.9 & -58.2 \\
\hline B-5A & 5069735 & 464508 & 12 & -9.23 & -9.48 & -8.96 & -61.0 & -62.9 & -57.5 \\
\hline $\mathrm{PP} 23 / 5$ & 5070000 & 463733 & 12 & -9.07 & -9.59 & -8.74 & -61.2 & -64.5 & -58.9 \\
\hline PZ-11 & 5071787 & 459757 & 12 & -9.26 & -9.80 & -9.04 & -62.2 & -66.4 & -59.1 \\
\hline PZ-26 & 5071720 & 459900 & 12 & -9.16 & -9.46 & -8.97 & -61.0 & -63.1 & -58.9 \\
\hline PZ-33 & 5071999 & 459721 & 12 & -9.12 & -9.64 & -8.22 & -60.4 & -64.8 & -53.5 \\
\hline $\begin{array}{l}\text { Sava } \\
\text { River }\end{array}$ & 5070125 & 466545 & 56 & -9.47 & -10.33 & -8.54 & -62.8 & -69.9 & -55.6 \\
\hline Precipit. & 5075122 & 459015 & 24 & -9.44 & -14.64 & -3.34 & -67.6 & -109.4 & -23.9 \\
\hline
\end{tabular}
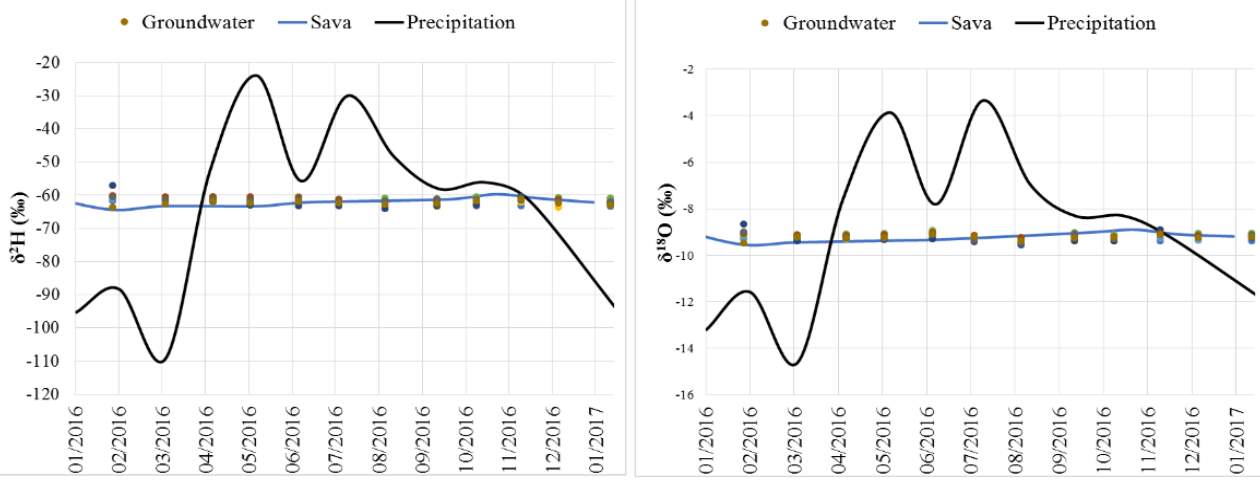

Fig. 2. Variations of $\delta^{2} \mathrm{H}$ and $\delta^{18} \mathrm{O}$ values in precipitation, groundwater and the Sava River during 2016. 


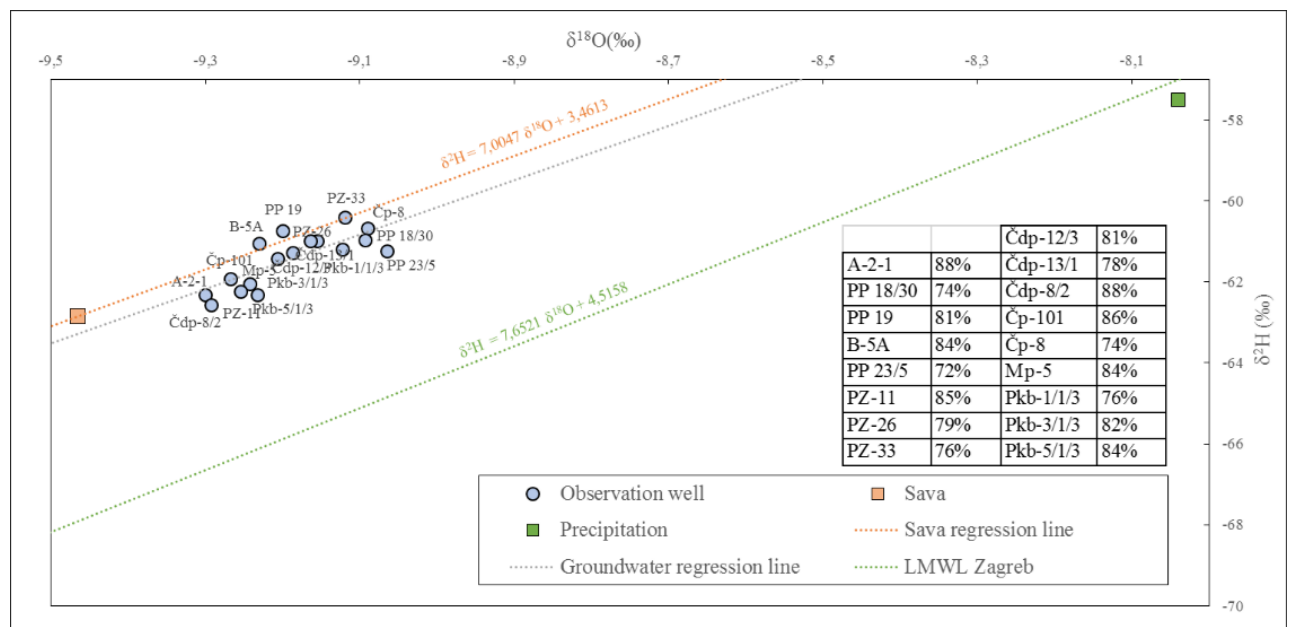

Fig. 3. Relationships between mean $\delta^{2} \mathrm{H}$ and $\delta^{18} \mathrm{O}$ of groundwater, precipitation and the Sava River water with the regression lines of groundwater and Sava River water, the Zagreb Meteoric Water Line (LMWL) and calculated fraction of the Sava river water $\left(\mathrm{f}_{\mathrm{sw}}\right)$ in groundwater.

\section{Conclusion}

The results of environmental isotopes measurements in groundwater near Sava River in the Zagreb area indicate strong connection between Sava River and nearby observation wells. Stable isotope analyses showed similar range of $\delta^{2} \mathrm{H}$ and $\delta^{18} \mathrm{O}$ values for the Sava River and groundwater samples with higher variations in surface water. Accordingly, mixing of water from the Sava River and groundwater is occurring in the near vicinity of the Sava River and it weakens further away. Furthermore, local precipitation has a small contribution in groundwater recharge ( $20 \%$ in average) and attention needs to be directed to Sava River. The results of this study allow better understanding of the relationship between surface water and groundwater and consequently more precise monitoring plans and definition of the sanitary protection zones of the nearby well fields.

\section{References}

1. Z. Nakić, S. Ružičić, K. Posavec, M. Mileusnić, J. Parlov, A. Bačani, G. Durn, Geologia Croatica, 66/1, 55-77 (2013)

2. N. Horvatinčič, J. Barešić, I. Krajcar Bronić, K. Karman, I. Forizs, Cent. Eur. Geol., 54, 121-127 (2011)

3. P. Vreča, I. Krajcar Bronić, A. Leis, M. Brenčič, Geologija, 51/2, 169-180 (2008) 